\title{
Strategic Interventions in Tackling Poor Performance of Service Departments: Study on Muhibbah Engineering (M) Bhd, Malaysia
}

\author{
Sekar Gopal, Dileep Kumar M. \\ Othman Yeop Abdullah Graduate School of Business, Universiti Utara Malaysia \\ dileep@uum.edu.my
}

\begin{abstract}
This case study describes the problems faced by Muhibbah Engineering (M) Bhd group of companies (Malaysia) due to the poor performance of it's service departments. This case was identified as a result of declining organizational performance of the company from the starting of year 2011 to early 2013. The main issues are declining profits (losses), delay in completing projects, customer complaints, skill depletion and poor organizational culture in the group besides other associated issues. The data related to the problems \&issues are collected through personal discussions with the Project Directors of the company, company's financial reports, financial research reports related to the company and through company's website articles. The analysis is done on the inputs based on proven management concepts and theories such as leadership styles, organizational culture, span of control, performance management, human behavior and so on. The steps taken to mitigate the problems and the solutions are identifed through the changes made in the company through strategic interventions. The outcomes of each of the major interventions are recorded in this case study for the readers to understand and experiment them in similar and or different situations as the outcomes are positive and proven to be effective.
\end{abstract}

Keywords: Strategic Intervention, service, performance

\section{Introduction}

Year 2011, MuhibbahEngineering suffered RM 245 million losses in Asia Petroleum Hub project and the share prices of the company crash down. The Board of Directors of Muhibbahgroup decided to bring in the young educated family member CJ Mac into the group as Director, who is the elder son of the founder of the company Mac Ngan Boon. C.J Mac acadamically educated in the west in Engineering and Business join the Board of Directors and started his work as Business Development Director guided by the father and the rest of the Board of Directors. From it's inception in the year 1972, Muhibbahengineering group traditionally known and very famous for marine related construciton works was a preferable construction provider for the marine ports construction in Malaysia\& Singapore. Most of the Government, Public \&Private sector companies look for Muhibbah Engineeringto do this type of big projects due to the track record and the professionalism shown by Muhibbah Engineeringwith it's resources. Over the period of last 42 years, the marine constuction industry become very competitive in nature and Muhibbah Ebgineering is forced to compete with companies like IJM Corporation, Gamuda, WCT, Eversendai and many smaller companies competing in this type of projects. As a result, the group was finding it very difficult to get new projects due to political, economical \& social influencing factors. This lead to skills migration to competitors and the service departments such as HR \& Admin, Quality Assurance, Safety, IT, Plant \& Assetwere performing below satisfactory levels due to the organizational hierarchical set up. Muhibbah Engineeringstarted incurring losses due to aforesaid issues by the year 2011, which influenced the management to bring C.J Mac on the Director's board.

C. J Mac studied the overall company's affairsand started observing the organizational culture of the company, core processes performance and the service departments performance critically as a young Director. He also studied the strength and weaknesses of the group with specifc reference to core processes and service departments. His prior experience as a project engineer for 5 years in various projects of Muhibbah Engineeringhelped him to understand the real issues faced by the projects due to the poor performane of service departments. His interaction with the elderly Directors and the peers from other companies gave him more insgiht into the business and he is clear on what exactly need to be done in the company for betterment. 
This has resulted in 3 major strategic interventions of the management besides others, which are described in details in the following pages. As a result of these 3 major interventions, the company restrcutured the business processes of the company during the starting of the year 2013 aggressively and rolled out these 3 major initiatives.This has resulted in improved service departments performance as well as the core proesses and started to gain good profits and moving forward now.

The Profile of the Company: Muhibbah Engineering Bhd, shortly called as Muhibbah is the parent company of Muhibbah Group of companies located in Klang, Selangor - Malaysia (source: www.muhibbah.com,2014).Muhibbahis a public listed company on the Main Board of the Kuala Lumpur Stock Exchange (KLSE) (source: Bursa Malaysia - Stock code 5703, 2014). Muhibbah is renowned for being a leader in Marine Construction since its incorporation in 1972. Today, Muhibbah stands firm in various disciplines of Engineering Construction, both locally and internationally (source: Insider Asia Sep'2013, 2014).Over the last 42 years, Muhibbah has established itself as a renowned international oil and gas and marine engineering specialists providing engineering, procurement, construction and commissioning (EPCC) of LNG jetty, oil terminal, oil storage tanks, gas pipes laying, bunkering facilities, ports, bridges, dams , marine facilities and infrastructure works in Southeast Asia, Middle east and North Africa.

Muhibbah also wholly-owns a shipyard named Muhibbah Marine Engineering (MME), which builds anchor handling tug boats, supply vessels, accommodation ships as well as ship repair services to the offshore oil \&gas Industry. Muhibbah also has the following subsidiaries, which are specialized in their respective field of engineering:

- MSI - Muhibbah Steel Industries Sdn Bhd - Fabricating steel structures.

- MPE - Muhibbah Petrochemical Engineering Sdn Bhd - Oil \&gas, piping, petroleum and gas storage tanks fabrication.

- MASI - Muhibbah Airline Support Industries Sdn Bhd - Design, fabrication and supply of airway bridges and its maintenance.

- CiTECH - CiTECH Energy Recovery Systems Malaysia Sdn Bhd - Oil \&gas platforms waste heat recovery units fabrication and supply.

- MEB CON - Muhibbah Engineering Construction Division - Construction of buildings \&infra Projects.

Muhibbah group employs close to 1,200 professionals / employees in approximately 10 countries and also employs approximately 6,000 sub contracted employees in its projects and subsidiaries. The group's overall turnover per annum stands as of now at RM 2.5 billion (source: Insider Asia - Sep'13, 2014). The group has ambitious plans to increase the turn over to RM 4 billion within the next 3 to 5 years and working aggressively towards achieving this target. Muhibbah group's vision\& mission statement is "Forging ahead with Globalization and focused diversification in the pursuit of excellence". Muhibbah is currently going through a strategic restructuring program due to the entry of C.J Mac as the Director to the Board since year 2011.

Problems: Muhibbah has grown up organically from a smaller company to a bigger corporate group over the last 42 years. When the company was smaller, the following departments were created to take care of the business processes.

\section{Core Processes (Project Management Departments): \\ - Tendering \& Contracts \\ - Procurement \\ - Project Management \\ - Accounts \& Finance}

\section{Supporting Processes (Service Departments):}

- HR \& Admin

- Quality Assurance

- Safety

- IT

- Plant \& Asset 
Figure 1: Muhibbah Engineering Organization Chart

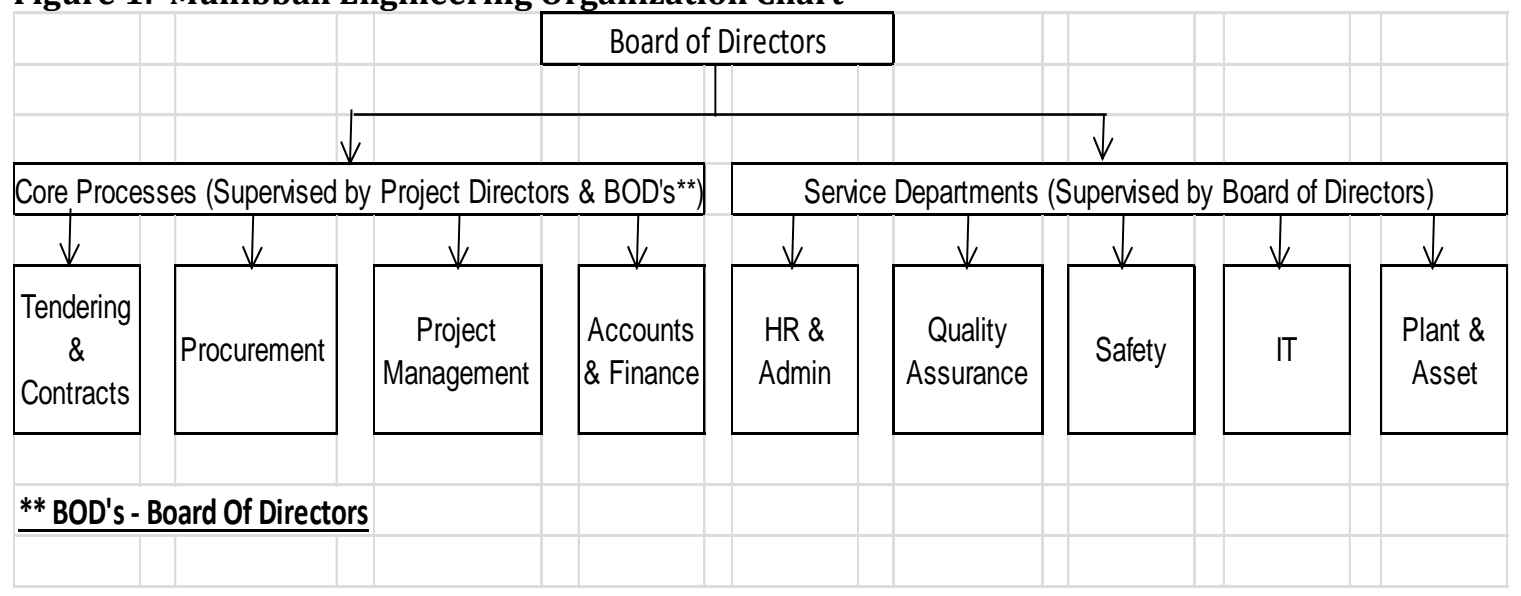

The Head of Departments (HOD's) of these processes / departments were reporting directly to the Board of Directors on the affairs of their departments, whilst, the core processes HOD's are reporting in parallel to the Project Directors too, who are responsible for the performance of Muhibbah's projects. As the business grew up, the company has grown to a corporate company with many subsidiary companies like MSI, MPE, MASI, CiTECH, MME and there were similar type of departments / processes created in the subsidiaries to handle the above processes and the Head of Departments of the parent company Muhibbah were promoted as Corporate Managers to take care of the processes related to Muhibbah's projects as well as the subsidiaries processes. Accordingly, the Corporate Managers started to look into the affairs of the parent company and also the subsidiaries on their respective areas and reported the performance to the Board of Directors. The Corporate Managers of these processes liaise with the Project Directors, Project Managers of the parent company projects as well as the Subsidiary heads.

The Board of Directors used to monitor the Corporate Manager's performance based on their understanding and decisions were made accordingly. As the years passed by, the group has grown and Board of Directors became too busy with the business unit's performance and business growth related issues. Accordingly, their main focus has been on the performance of the core processes rather than the supporting processes performance (service departments) and the Corporate Managers responsible for the service departments were really not supervised on their performance for a prolonged time period. This has led to the following organizational culture:

- Corporate Managers of service departments not attending the office regularly and in time.

- Corporate Managers of service departments doing their own business and personal works at office hours.

- Corporate Managers of service departments working without any specific objectives or KPI's and attending to the daily routine works, without any commitment.

- Corporate Managers of service departments working with low morale and enthusiasm.

- Very low accountability and job satisfaction at Corporate Managers of service departments.

- Service departments Corporate Managers were on PAEO (Perceived Alternate Employment Opportunity) culture and so on.

The above organizational culture, lead to the development and aggravation of the following problems:-

\section{Problems faced by the Core Processes}

- Cost overrun in many of the projects undertaken.

- Substantial delay in completing the projects.

- Additional cost spending due to quality defects / reworks and delivery related issues in projects.

- Less profit margin to the company.

- Share prices of the company falling down below its issued price.

- Loss of credibility and company image. 
- Lack of innovation, knowledge management \& automation.

- Loss of competitive advantage.

\section{Problems faced by the Service Departments}

- Customer complaints on quality of works carried out in the projects.

- Accidents, Incidents, LTA's (Lost Time due to Accidents) in projects.

- High Employee turnover and absenteeism.

- Low morale of the employees.

- Too old IT operating systems / software with outdated equipment and poor compatibility without any proper policy and framework to meet the technological changes happening in the industry

- Plant and Assets purchased are not properly maintained leading to frequent breakdowns, down times, expensive repair works, unnecessary hiring of outside equipments due to own equipments breakdown etc.

- Skills migration and depletion from the company.

\section{Problems faced by the overall organization}

- Project managers and subsidiary heads were not listening to the instructions of the Corporate Managers of service departments.

- Favoritism culture.

- Variation in compensation and unstructured promotions \& benefit grants,

- Lack of transparency in personnel and administration activities,

- Lack of performance and learning culture in the organization.

\section{Strategic Interventions}

Followed by the financial losses in the year 2011, understanding the need to restructure the company and to improve the performance of the business and the service departments performance, the Board of Directors decided to bring the young educated family member CJ Mac into the business and the second generation director took charge of the business under the shadow leadership of the elderly directors. The young director has relevant education academically from a recognized university in the west and has played observatory role for a period of 2 years in the company (besides 5 years' experience in projects as Project Engineer) studying the culture of the company and the business performance. CJ Mac continuously orient with the various department heads of core processes as well the service departments to understand the existing issues of the company and constantly / carefully discussed the issues with the elderly directors and got their inputs and advices on matters of business interest.

After 2 years of study, the young director C.J Mac. Put up a restructuring plan to the Board of Directors, highlighting the following areas:

- Business Diversification from normal construction to Oil \& Gas construction + normal construction.

- Restructuring the construction business into 3 major business areas like Airport, Building\& Infrastructure (ABI), Marine and Oil \& Gas with dedicated Project Directors responsible and accountable for business performance of each sector.

- Assigning additional responsibilities to the Project Directors to enhance the performance of the UNDER PERFORMING service departments efficiency to the required levels.

Accordingly, the poorly performing service departments were given the directive to report directly to the Project Directors of the 3 business areas as follows with effect from 01/01/2013:-

- ABI Project Director $\quad$-Responsible for HR \& Admin Department, IT Department.

- Marine Projects Director - Responsible for Plant \& Asset.

- Oil \& Gas Projects Director- Responsible for Quality Assurance \& Quality Control, Safety.

Key Performance Indicators (KPI's) were set for each of these 3 Project Directors for their own area of business as well as for the service department's performance. The service departments Corporate Managers were asked to report their department's performance and affairs to these Project Directors on a day to day 
basis. This has resulted in establishing KPI's for the service departments as well, which were not there before. These KPI's were linked to the service department's Corporate Manager's yearly performance review for promotion, increment, bonus and other performance related rewards.

\section{Outcomes of each Intervention}

Intervention - 1 - Business Diversification - Outcome: This was the major policy change in the company's business decision ever, which drove the company to seriously study the requirements of Oil \& Gas sector, which led to the following:

- To collaborate with major Oil \& Gas players in the world like Shell, Exxon Mobil, PETRONAS and BP etc.

- The above has created an opportunity to participate in constructing a biggest LNG Oil \& Gas project** in Melaka. Muhibbah successfully completed the project with the satisfaction of the client and led to the recognition by PETRONAS and got awarded with PETRONAS License to do major Oil \& Gas projects in Malaysia and other parts of the world.

- As PETRONAS License is a very difficult recognition to achieve and since it is limited to only handful of companies in Malaysia, soon after getting the license, Muhibbah's share prices climb up from RM 0.8 / share to RM 2.5 / share.

- Today, Muhibbah is tendering a lot of Oil \& Gas projects in Malaysia and overseas, which has good potential for success and growth of the company.

Intervention - 2 - Restructuring the Construction Business - Outcome: Restructuring the construction business and division of business resulted in the birth of 3 major construction sectors within the company, which in turn resulted in the following:

- Project Directors become more responsible \& accountable for their own business areas and they really take care of their business areas in their own ways\& styles for betterment of their sectors.

- Authority given to them on their area made them to take decisions quickly and execution became faster.

- Competitive aggressiveness came in and each Project Director is trying to compete with each other in terms business performance, revenue creation, innovation, customer satisfaction etc.

Figure 2: Muhibbah Engineering - Business Diversification. (Source: Project Directors, 2014)
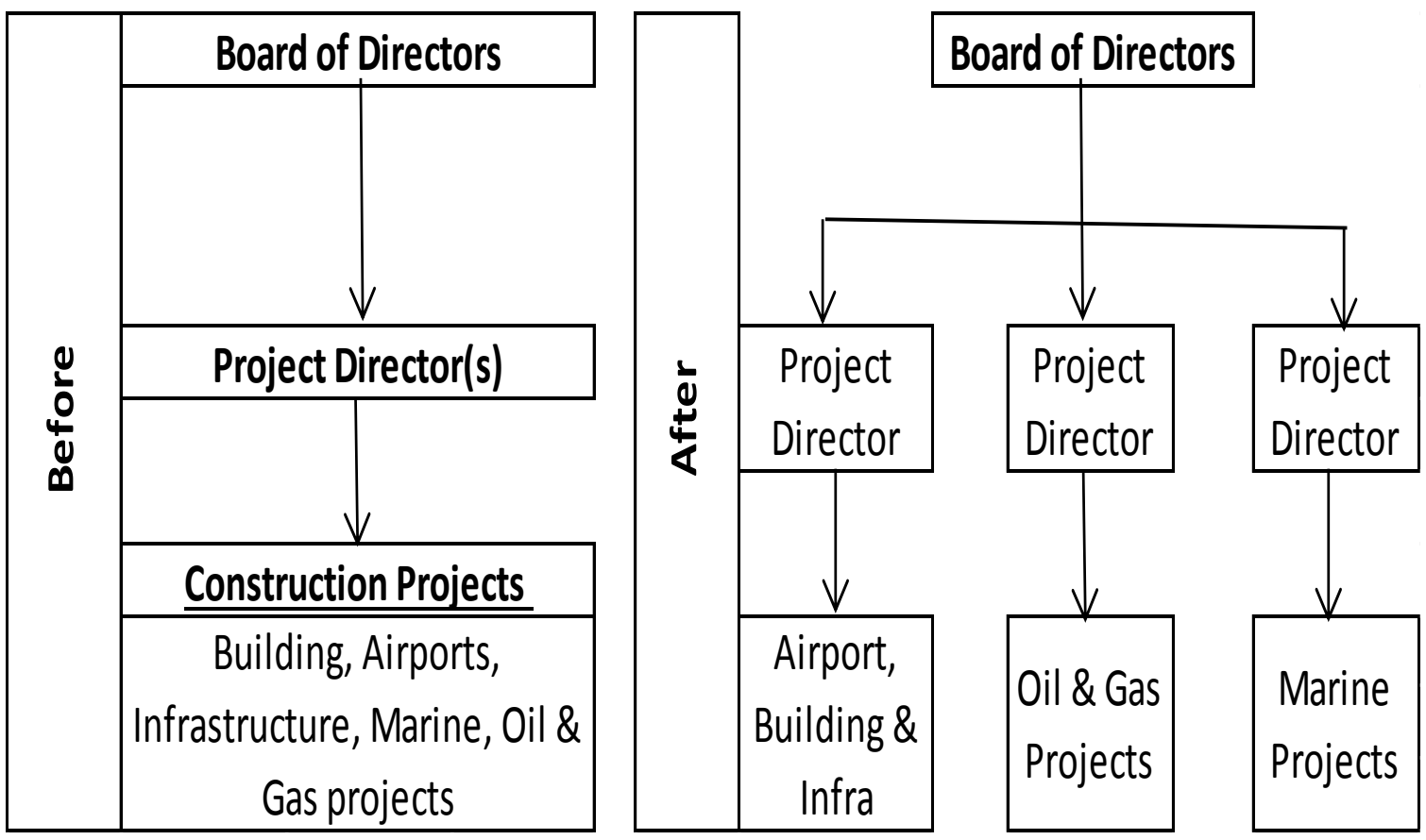

Figure 3: Muhibbah Engineering Share Price trend (Source: Yahoo Finance, 2014)
MUHIBBAH ENGINEERING (M) BHD

- $5703 . \mathrm{KL}$
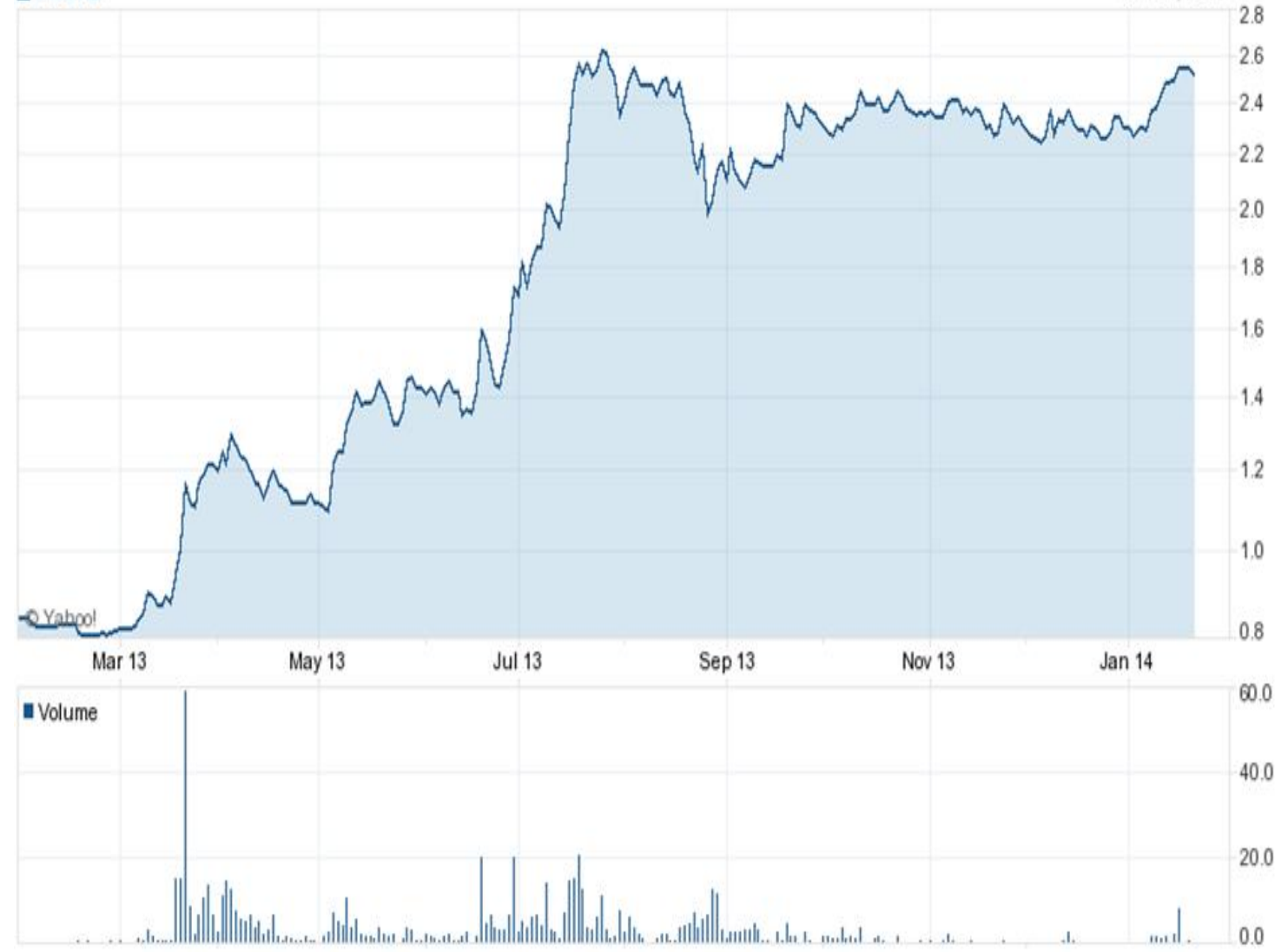

Share prices shot up from RM 0.8 / share to RM 2.5 / Share due to the strategic interventions of the management mentioned above.(Source: Yahoo Finance)

Intervention - 3 - Assigning Additional Responsibilities to Project Directors to Oversee Service Departments - Outcome: Assigning additional responsibilities of service departments to the Project Directors resulted in the following:

- Service departments Corporate Managers were given KPI's to achieve and their performance were critically reviewed.

- Complete outlook and the way the service departments operate were questioned and many strategic changes were introduced in this departments such as addition of performing new employees, removal of non performing employees, introduction of new procedures, introduction of new software / methodology etc.

- Regular meetings were conducted by the Project Directors with their respective service department teams and the progress of the service departments went up considerably.

- This has resulted in improved service departments performance, which led to the improvement of the core business processes performance and hence the overall company performance. 
Figure 4: Muhibbah Engineering - Service Departments Responsibility Assignment. (Source: Project Directors, 2014)

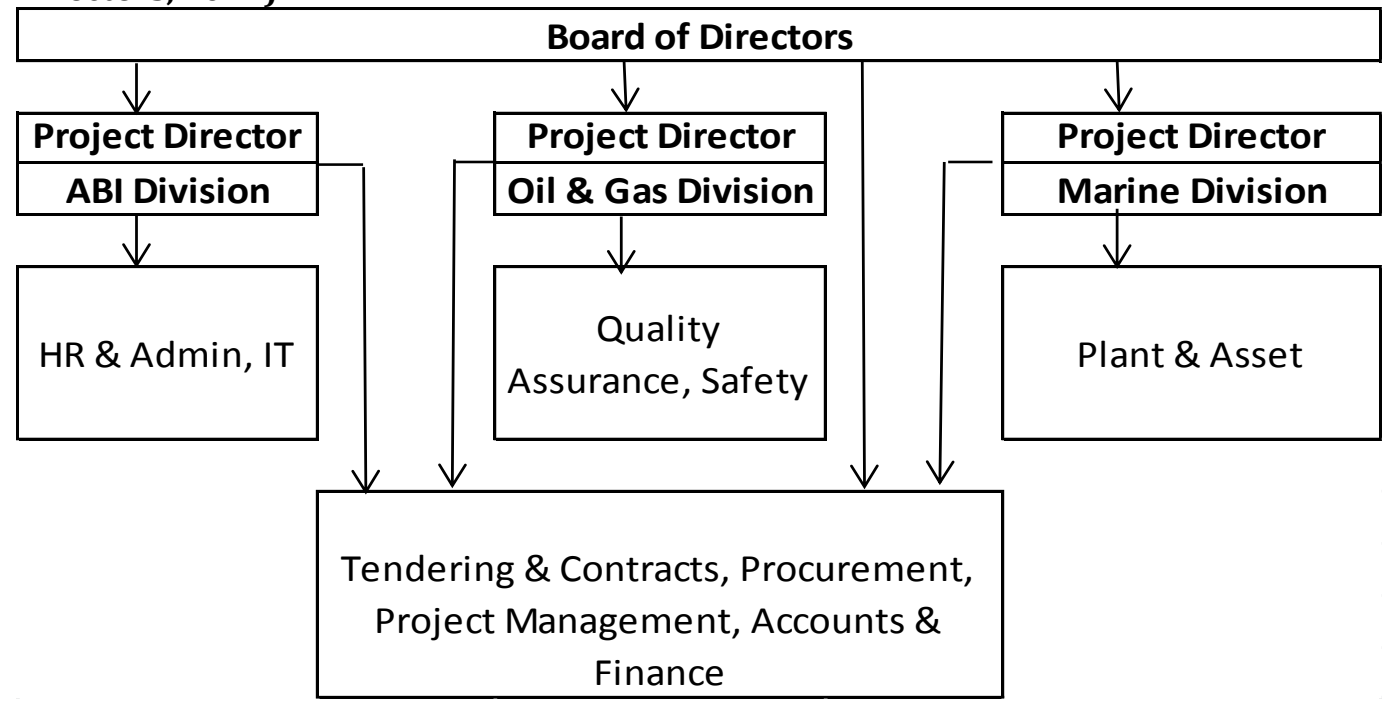

\section{Justification of Managerial Decision Making and Critical Analysis}

While analyzing the above critically, the following are evident.

\begin{tabular}{|c|c|}
\hline Area & Analysis \\
\hline Service Departments Performance & $\begin{array}{l}\text { Important for the Organization's Performance as it has direct } \\
\text { correlation to the core processes and its performance. }\end{array}$ \\
\hline Human Behavior & $\begin{array}{l}\text { Irrespective of whether the employee of a company is a worker or } \\
\text { a Corporate Manager, monitoring and supervision is necessary to } \\
\text { ensure continued performance of the individuals. Prolonged } \\
\text { omissions will lead to poor performance and dissatisfaction to both } \\
\text { employers as well as employees. }\end{array}$ \\
\hline Business Succession Planning & $\begin{array}{l}\text { For family owned companies, when the owners of the first } \\
\text { generation is getting elder, introduction of the second generation is } \\
\text { essential with proper supervision to turn around as well as to } \\
\text { sustain the business. }\end{array}$ \\
\hline Business Process Re-engineering & $\begin{array}{l}\text { When the organizations are not performing upto satisfaction, the } \\
\text { critical need for Business Process Reengineering arises. }\end{array}$ \\
\hline Business Diversification & $\begin{array}{l}\text { At appropriate times, organizations need to diversify their } \\
\text { businesses for better performance. }\end{array}$ \\
\hline Business Performance Management & $\begin{array}{l}\text { For sustainable performance and improvement, KPI's (Key } \\
\text { Performance Indicators) are necessary to guide the departments } \\
\text { towards performance. }\end{array}$ \\
\hline Organizational Culture & $\begin{array}{l}\text { Organizational performance is highly related to the organizational } \\
\text { culture. Better culture improves performance and vice versa. }\end{array}$ \\
\hline Leadership Styles & $\begin{array}{l}\text { Leadership styles of top management have direct relationship to } \\
\text { the performance of the organization. If the leaders neglect certain } \\
\text { areas in the organization, the chances are, there will be problems } \\
\text { at a later stage. }\end{array}$ \\
\hline Span of control & $\begin{array}{l}\text { It is evident from this case study that, even though there are well } \\
\text { experienced Directors on the Board, the company's performance } \\
\text { can go down if they do not have time to supervise the departments } \\
\text { reporting to them directly. }\end{array}$ \\
\hline Flux Leaders & $\begin{array}{l}\text { Second generation leaders of our times has a distinct advantage } \\
\text { over others in the sense that, they are academically educated in }\end{array}$ \\
\hline
\end{tabular}



innovation, out of the box thinking and so on.

Empowerment of individuals lead to improved performance is evident in this case study as the Project Directors assigned with additional responsibility brought in improved performance and competing culture in the company.

\section{Conclusion}

It is evident from the above case study that, neglecting service departments' performance over a prolonged period of time can lead to poor performance of the service department's deliverables, which will affect the performance of the core processes subsequently. This will have a direct impact later on the overall business performance of the company. Strategic interventions are necessary to sustain the business and serious business re alignments become mandatory for improvements in business performance. Many first generation companies suffer serious damages during the elderly stages of the founders due to this fact and those companies, who did the adjustments and succession continued to enjoy the sustainability, growth and stability. Injection of new talents and young thoughts in the organization in the form of educated young Directors entry to the organization under the shadow leadership of elderly Directors is a good combination for successful organizational turn around. The above points were evidently proved from the above case study in Muhibbah Engineering, in which the poor performance of service departments were realigned along with the Business Process Reengineering initiatives, which turned the company towards successful path. Today, Muhibbah Engineering Share price stands at RM 2.5 / share and expected to go up to RM 3.25 / share by mid2014 as per the predications of the financial advisory sources. By understanding this big leapfrog change in the company, we can generalize that, Service Department's performance is crucial for every organization's sustainability and success.

\section{References}

Insider Asia by Asia Analytica (2013). Muhibbah Engineering (M) Bhd, Financial research reports. Retrieved fromhttps://www.google.com/webhp?tab=ww\&ei=jLHsUuGWH-boiAeCtIGYCQ \&ved= OCBQQ1S4 $\# q=$ muhibbah+engineering+losses. (Retrieved on $7^{\text {th }}$ Feb, 2013)

Muhibbah Engineering Bhd (2014). Vision Statement. Retrieved from www.muhibbah.com. (Retrieved on $20^{\text {th }}$ Feb, 2013)

Muhibbah Engineering Bhd (2014). Annual Report. Retrieved from http://www.muhibbah.com/ user files/file/muhibbah_AR_2012.pdf. (Retrieved on $12^{\text {th }}$ Feb, 2013)

Yahoo finance (2014). KL Historical Prices. Muhibbah Engineering (M) Bhd. 2014. Retrieved from https://www.google.com/webhp?tab=ww\&ei=jLHsUuGWH-boiAeCtIGYCQ\&ved=0CBQQ1S4\#q = muhibbah+engineering+share+price. (Retrieved on $14^{\text {th }}$ Feb, 2013). 